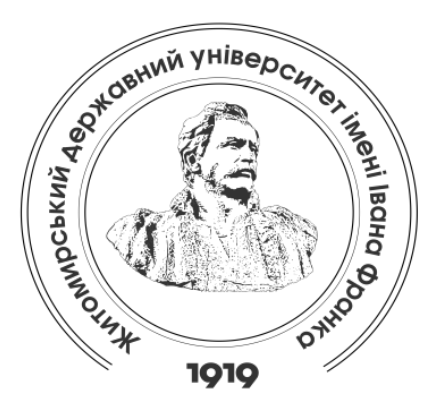

Zhytomyr Ivan Franko State University Journal. Philosophical Sciences. Vol. 1(87)

Вісник Житомирського державного університету імені Івана Франка. Фімософські науки. Вип. 1(87)

ISSN: $2663-7650$

\title{
UDC 2.128:316.6:7.097 \\ DOI 10.35433/PhilosophicalSciences.1(87).2020.26-37 \\ UNCERTAINTY AS A PREREQUISITE FOR THE UPDATING OF HUMAN ESCHATOLOGICAL VIEWS IN THE MODERN WORLD
}

\section{K. Vitiuk*}

The article deals with the peculiarities of eschatological views of man and society in the world processes going on nowadays. The author pays attention to the fact that eschatological views are to a greater or lesser extent typical for both believers and the secularized population. Eschatological views of a modern person are considered to receive a new impetus to actualization due to the uncertainty of future prospects of humanity prospects of humanity as a whole and each individual as well. It is noted that since the twentieth century, "any ultimate goals of history", not necessarily apocalyptic, are considered eschatological events.

Uncertainty about the future provokes deep fears of a person, one of which is the fear of death. In the context of this study, the fear of death, alongside with the fear of the unknown, is interpreted a factor in the formation or strengthening of eschatological views. In a contemporary person's mind, they are formed and re-formed due to uncertainty caused by one of the most stressful events of 2019-2020 - the Kovid-19 pandemic.

The mass media play a significant role in spreading eschatological views in the modern world, highlighting not only facts and statistics concerning it, but also speculations about the pandemic. We can observe two major trends: who foresaw modern events and how it will end according to the "prophecies" of varying degrees of trust. Considerable attention is paid to literary and cinematographic works, which provided, in one way or another, contemporary events. The popularity of genres made the works in question widely spread and discussed. "Conspiracy theories" are also analyzed, as they occupy a special place in explaining the causes of nowadays events.

The article considers the impact of a pandemic on a person in modern social interactions, who is in a state of anxiety due to the possibility of losing the necessary social ties, place of work, etc. The author also points to some features of social eschatological nature that were provoked by Kovid-19 pandemic. Some disturbing prospects that may take place in the future and manifest themselves in the sphere of social eschatology are outlined.

Keywords: Symbolic Production and Exchange, Everyday Life, Situation of Uncertainty, Religious Experience, Eschatological Views, Eschatological Prediction, Eschatological Myth, Fear of Death, Social Anxiety, the Covid-19 Pandemic, Social Eschatology.

"Candidate of Sciences (Philosophy), Docent

(Zhytomyr Ivan Franko State University, Zhytomyr, Ukraine)

irenevik@i.ua

ORCID: 0000-0002-2998-6323 


\section{НЕВИЗНАЧЕНІСТЬ У СУЧАСНОМУ СВІТІ ЯК ПЕРЕДУМОВА АКТУААІЗАЦІї ЕСХАТОАОГІЧНИХ ПОГАЯДІВ АЮДИНИ}

\section{K. BiTrok}

У статті розкриваються особливості есхатологічних поглядів людини і суспільства у сучасних загальносвітових процесах. Звертаеться увага, шо більшою чи меншою мірою вони присутні як у віруючих, так і секуляризованого населення. Есхатологічні погляди сучасної людини розглядаються як такі, шо отримують новий поштовх до актуалізаиіі завдяки невизначеності майбутніх перспектив людства загалом $і$ кожної окремо взятої людини зокрема. Зазначається, шо починаючи з XX cm., есхатологічними подіями починають вважати "будь-які кіниеві иілі історії", не обов'язково апокаліптичні.

Невизначеність майбутнього провокуе глибинні страхи людини, одним із яких є страх смерті. у контексті даного дослідження страх смерті інтерпретуеться, наряду із страхом перед невідомістю, як чинник формування чи посилення есхатологічних поглядів. у сучасної людини вони формуються і реформуються через невизначеність, спричинену однією з найбільш стресових подій 2019-2020 рр. - пандемією Ковід-19.

Значну участь у поширенні есхатологічних поглядів у сучасному світі відіграють засоби масової комунікаиії, піднімаючи тему не лише фрактів і статистики, а й спекуляиій довкола пандемії. Популярними у такому сенсі стали два основні напрями: хто передбачив сучасні події $i$ як усе скінчиться відповідно до "пророцтв" різного ступеня довіри. Значна увага приділяеться літературним та кінематографічним роботам, у яких було передбачено в тому чи іншому вигляді сучасні події, увага до яких пояснюеться популярністю жанрів. Проаналізовано також "теорії змов", які посідають окреме місие при поясненні причин сучасних подій.

У статті розглянуто вплив пандемії на людину в сучасних соиіальних взаємодіях, яка перебуває у тривожному стані через можливість втрати потрібних соиіальних зв'язків, місия роботи та ін. Указано деякі ознаки соиіально есхатологічного характеру, які мали місие у зв'язку з Ковід-19. Окреслено деякі тривожні перспективи, які можуть мати місие у майбутньому і проявитися у срері соиіальної есхатології. Зазначено, що есхатологія також сприяе актуалізаиї способів подолання трагізму ситуаиї невизначеності 8 повсякденному житті соиіуму та страху перед ї̈ наслідками.

ключові слова: символічне виробництво та обмін, повсякденність, ситуаиія невизначеності, релігійний досвід, есхатологічні погляди, есхатологічний прогноз, есхатологічний міф, страх смерті, сочіальна тривога, пандемія Ковід-19, соиіальна есхатологія.

Introduction of the issue. Eschatological issues at the present stage of philosophical thought development are considered in the context of many sciences and humanities, and this fact testifies to the public demand for an answer to one of the most important questions of human existence: the question of life and death. The presence of eschatological research, for example, in natural sciences, eloquently points to the specific expectations and anxieties of a contemporary person, caused not only and not so much by religious views, but the risks of everyday life in the modern world. And, therefore, today we can consider eschatological views not only as a compound part of religious consciousness, but also regardless of the latter. Thus, representatives of the natural sciences make attempts to study the principles of scientific scenarios of earth history eschatological development (V. Chumakov, A. Velikman, A. Shalygin, O. Arsenov) [1]. Within the main aspects of concept of "eschatology" comprehension there are two main approaches to the interpretation of the finiteness of existence (individual or collective): "ultimate destiny /fate" and "ultimate 
goal", "absolute (final) goals". Moreover, aspects of "destiny" are manifested mainly in individual eschatology, and "goal", "purpose" in general. General eschatology focuses on "the purpose of space and history", "exhaustion of their meaning" [2: 97]. Today, in the context of religious doctrines that have an eschatological component, eschatology is a "self-transcendence of the accelerated course of history" [2: 102] and in this form acquires a new round of its relevance.

It is characteristic of Ukrainian religious thought to reflect on eschatological issues in several directions. Thus, in connection with utopian scenarios, eschatology is considered in the context of the sociophilosophical paradigm. Due to utopian scenarios eschatology is considered in terms of socio-philosophical paradigm. In particular, M. Fomenko in the study "Worldview origins of modern eschatological consciousness" (2007) [3], raises the issue of eschatological consciousness sources as semantic guidelines, which reflect the end of existence. The researcher emphasizes the actualization of eschatological issues, giving examples of understanding the future, produced in the form of anthrop-, socio- and geocatastrophe scenarios. It is worth mentioning, that in the 21 st century, scenarios that combine all three of these factors look realistic: a geocatastrophe caused by human activity, which results in far-sighted consequences in the field of social eschatology.

R. Granin points out an essential feature of the XXI century eschatology, namely its transformation into a "phenomenon of mass culture" [4: 4], in which the leading role belongs to the media, enhanced by the global digitalization of the modern world. Apocalyptic and post-apocalyptic feature films have ceased to be exotic since the end of the last century, and global access to information on the Internet opens new horizons for understanding multi-scenarios of the world end in its multiple variations. Along with the traditional understanding of eschatology in the confessional expressions of a particular religious doctrine, among the secularized population there is interest in eschatological ideas, which is always relevant to the social, political or environmental challenges of the modern world, as well as various "conspiracy theories".

It should be noted that eschatological views get actual in situations of instability, shocks, crises, local and global catastrophes, which are directly or indirectly related to the disruption of the normal course of everyday life. In other words, they depend on situations of uncertainty, which can significantly affect the state of man and society.

Many authors define uncertainty, in fact, by the proximity of its meaning to other concepts, namely: problem situation, the unknown, situations of frustration, randomness and unpredictability, and others [5: 140]. It is fair to say that uncertainty in the modern world is primarily related to the Covid-19 pandemic.

Comprehensive research of eschatology phenomenon has led to its specification into the areas: "realized", "consistent", "micro"/"macro", "inaugural", "futuristic", "existential", "space", "individual", "catastrophic"," apocalyptic" eschatology and others. Since the XX century the term "eschatology" began to define "any ultimate goal of history", not necessarily apocalyptic [4: 54]. Thus, it is fair to say that eschatological were the moments in world history when the system of collective security collapsed after the two world wars. The Covid-19 pandemic is, in fact, that kind of event, which revealed the pressing problems of the human life and health system, 
helplessness in confronting the world community with threats such as viruses, biological weapons, and the global economic crisis with all possible consequences. Assuming that the statement (according to one of the conspiracy theories) about the artificial origin of the Covid-19 coronavirus is true, terrorism with the use of biological weapons can be a big problem on an eschatological scale.

The outline of unresolved issues brought up in the article. The eschatological issue has gained a special burst of relevance in connection with the most dramatic event of 20192020, which "put the world on hold" the Covid-19 pandemic. The threat of a disease caused by a new pathogen, against which there are currently no means of control in the world, makes humanity helpless, which is repeatedly reported by the world community in the person of WHO leaders, presidents of world superpowers and evidenced by morbidity and mortality statistics. The fundamental difference between this very pandemic, as well as the panic around it, and all previous epidemics is the speed of spread. The global world, as it turned out, has no borders that are insurmountable for viruses, and despite all the efforts of the world community to curb the spread of the disease, the onset of coronavirus Kovid19 does not give up. Such a situation quite naturally raises the ontological component in the human mind, putting them in the face of an unknown future, sometimes even the question of whether a future will take place. Uncertainty of this kind causes heightened anxiety over possible losses in the future. Optimistic scenario - overcoming the pandemic by humanity contains at the same time a pessimistic component: overcoming its consequences, the process of which will stretch over time indefinitely. And the scenario of the future, in which no vaccine against the virus will be found, involves the invention of ways of mankind's symbiosis with Covid-19.

Eschatological views are nowadays considered by scientists as part of the worldview of modern man and society (R. Granin, M. Fomenko, V. Dokash). There are attempts to substantiate the phenomenon of eschatological consciousness typical of human (J. Wiggins, O. Vena, I. Salevano, Ch. Stettler, M. Berdyaev, M. Fomenko, M. Nazarenko, O. Bilyanska), inherent in man. Researches of eschatological views of the person in a social context are carried out, as well as attempts to explain the actualization of eschatological views of a person caused by awareness of the threat of social ties loss (C. Routledge, A. Abeyta, Ch. Roylance). The problem of fear of death in connection with the emergence and strengthening of a person's eschatological views is researched (C. Routledge, F. Ilyasov, I. Vitiuk). Much attention is paid to the connection of eschatological views of the present with the Covid-19 pandemic (M. Bhandari, U. Brito, T. Olaopa). A promising area of study of eschatological issues is the reinterpretation of eschatological myth in the media space (A. Pozharov, D. Pavlich, etc.).

The purpose of research. The aim of the article is to analyze the situation of uncertainty in the modern world in the eschatological context: as a prerequisite for the actualization of eschatological views of a person and society.

Discussion and results. Without intention to analyze all the consequences of the Covid-19 pandemic (demographic, environmental, social, etc.), let's analyze the connection between the phenomenon of uncertainty caused by this pandemic, with eschatological and prophetic views in the minds of people nowadays, formed under the influence of popular culture and mass media. 
The pandemic "stirred up" the world at the economic, sociological and intrapersonal levels [6]. The latter aspect of the pandemic perception is the focus of our analysis, as the perception of information that has nothing to do with a person in time and space, and the understanding of the situation that affects everyone and moreover - is threatening are different in the strength of the impact on the worldview and inner state of a person. The uncertainty of the future of the world, known to us today, as well as the uncertainty of the individual existence of everyone, provokes anxiety that in one way or another touches upon eschatological aspects, whether it is fear, acceptance, or, on the contrary, the tendency to escapism. However, it can be caused by an extreme form of fear - horror, the intensity of which forces a person to internally dissociate from its pathogens / triggers.

A great role in increasing anxiety and fear in this situation belongs to the media, as since the pandemic and to this day they focus on mainly events related to the coronavirus, which affects the human sensory sphere. Prof. Medani P. Bhandari summarizes uncertainty as one of the features of the current state of world society by highlighting one of the messages that are heard today from all media: "is no guaranty of anything" [7: 1]. Anxiety about the uncertain future is also of eschatological significance, as it directly concerns the deepest, "fundamental" existential of human being - the fear of death. It is the fears of death, along with anxiety about the unknown, in our opinion, are at the origins of eschatological views. Today, more than ever, people feel helpless in the face of a new threat. We are frightfully aware that the technological achievements of mankind do not guarantee the preservation of human life. Man has failed to reveal one of the deepest mysteries of human existence - the mystery of death. If we consider the awareness of one's own mortality as a compound part of individual eschatology, it's true to suppose that eschatological views are universal and inherent in the worldview of each person. Death as a threat is now treated more real than ever; death as a future that can happen to anyone at any time; death as a near prospect is close.

Modern civilization due to the Kovid19 pandemic has found itself in a situation of complete frightening uncertainty, as Medani P. Bhandari says: "We are all scared, terrified, and with a phobia of uncertainty". And the most important question of this "phobic uncertainty" is the question of its consequences. Coronavirus destroys the social system we know. A person sick with Covid-19 should be in isolation, a person who died from Covid-19 should be buried without proper traditions and the presence of family members. Many people are caught in a pandemic in a foreign country with no means of subsistence, in a situation of uncertainty. Preventive isolationism is reflected in human existence in the loss of social ties; therefore, the uncertainty of the future in the Covid-19 pandemic also raises concerns about being outside society, social protection. According to Prof. Medani P. Bhandari, the loss of family members and the inability to say goodbye to them or be present during their most difficult times, can cause social phobia [7: 1-2].

There was revealed a direct connection between the fear of one's own mortality awareness and the comprehension of one's belonging to a social group, strong social ties. The stronger a person is ingrained in the social system, the easier it is to deal with the tragedy of mortality salience awareness or fear of death. Conversely, the lack of identification with social groups increases the fear of death, 
anxiety and undermines the inner balance of man [8: 6-7]. Thus, longterm social distancing during quarantine measures due to Covid-19 violates the sense of belonging to a social group and can not only adversely affect human well-being, but also threaten to increase the fear of death, social destruction or internal discomfort of a person.

No less threatening is the uncertainty of the future of man in the field of social eschatology, after all, there is reason to believe that the world is already on the path of "social devastation." This carries the threat of deviant behavior on a huge scale, because "necessity knows no laws", which in turn will destroy the world order we know. And it is difficult to predict the extent of social decline [7: 1]. Even at the beginning of the pandemic, one could see threatening signs of deviant human behavior caused by fear. For example, the protests in New Sanjary (Ukraine) (February 20, 2020), when stones were thrown into a bus with evacuees from China, covered by the epidemic; arson of a hospital where patients with coronavirus were (Iran) and others. It can be assumed that social eschatology in this context is manifested in several ways: 1) eschatological views, which indicate a person's confidence in the reality of the threat to his existence; 2) "loss of the human face" in an existential borderline situation, when, under the influence of fear, the biological dominates over the social, a person is under the influence of the collective unconscious. One of the real alarming prospects in this situation can be considered the threat of hunger, rising prices, inflation, unemployment, labor migration and others.

In the modern scientific field of research of eschatological issue its presence, in particular, in mediacultural space is considered. Thus, A. Pozharov highlights the transformation of Christian eschatological myth in the modern media-cultural space, emphasizing the image of the Apocalypse in the system of modern media culture. Analyzing eschatological views, rooted in the public consciousness, the author examines the disintegration of Christian eschatological myth as a whole and concludes that a new model of the Apocalypse in the modern world, which is eclectic in nature [9]. If we only superficially follow the apocalyptic scenarios that have taken place in cinema in recent years, we can say that the threat of an alien invasion, asteroid crash or other space catastrophe is much inferior to various viruses that threaten humanity in one way or another.

Among the apocalypse films, "Virus" (2016) and "Contagion" (2011) were strikingly similar to the Covid-19 pandemic. According to the plot of "Contagion", a global pandemic originates from Hong Kong, where a bat transmits the virus to a pig, and the main character receives it by means of a handshake with a chef who cooked pork. The airborne route of infection and the quarantine system of entire cities are also common with reality. Similarly, from China, according to the plot of the horror film "Virus", a pandemic of an unknown virus, from which the affected patients turn into zombies, begins. The film has both quarantine and a frivolous attitude to news of the epidemic as well as ignoring warnings and recommendations. In the horror film "Hostile" (2017), the virus turns people into carnivorous zombies, which are gradually displacing the rapidly declining human population. As the storyline unfolds, it becomes clear that this virus is of anthropogenic origin, and the first victims appear as a result of a chemical attack in the New York subway.

The situation with the spread of the flu epidemic in the United States is 
depicted in the animated series "The Simpsons" (1993). In the "Marge in Chains" series, the Osaka flu virus arrived in a parcel with a juicer from Japan, where factory workers infected it with the virus [10].

There has been a huge wave of speculation in the media about the pandemic's connection to the eschatological prophecies of both the ancient world and modern prophets (psychics, clairvoyants, astrologers), who somehow managed to predict something similar to what is happening around us now, and works of art. Thus, the authors of the predictions of the Covid-19 pandemic include Nostradamus, Wang, Gregory Rasputin, Bill Gates, Stephen Hawking, Paul Globa, and a number of lesser-known modern astrologers and seers. Plot-like storylines were once described in Stephen King's "The Stand" (1978), Jack London's "The Scarlet Plague" (1912), Dean Koontz's "The Eyes of Darkness" (1981), Sylvia Brown's "End of Days. Predictions and prophesies" (2008) and some others. In addition, a report by the Rockefeller Foundation's "Scenarios for the Future of Technology and International Development", prepared in 2010, of the four scenarios for the future development of mankind, the scenario called "Lock Step" describes a pandemic of a new strain of influenza, which kills about $20 \%$ of the population [10].

A very close prediction of the real state of affairs in the world today was made by Bill Gates in 2015, when there was an outbreak of the Ebola epidemic in Africa. In a speech on TED Talks, he said that the next epidemic could be spread by air, and patients may have no symptoms, which would create the ideal conditions for the spread of the pandemic around the world. The 32 billionaire drew attention to the vulnerability of the global health care system, the lack of associations of epidemiologists and trained doctors [11]. It is very tempting to accuse Gates or members of the Rockefeller Foundation of conspiracy theories to prove their own right, but such cases show that the world even then had the potential threat of such pandemics. And painstaking analytical work in the field of forecasting and prediction aimed not to intimidate with threats, but to warn the world community to prepare, point out weak vulnerabilities that remain so and therefore significant human losses, unfortunately, occur.

Among the others the performance of Madonna during the Eurovision Song Contest 2019 with the song "Future" was impressive. Madonna's stage costume included a crown (corona in Greek) on her head, and the dance group around her performed in gas masks. Moreover, at the beginning of the composition, people in gas masks were falling and rolling down the stairs. Currently, social media is spreading posts about how the singer managed to predict a coronavirus pandemic in this song. Even the lyrics can be interpreted, if desired, as reflecting the present: "Not everyone is coming to the future, not everyone is learning from the past" [12].

The eschatological fear of the uncertain future is evidenced by metaphors of biblical scale describing the coronavirus: the "gloomy reaper" for sinners [13], the "the phobia corona" [7].

Professor of Public Administration from the National Institute of Policy and Strategic Studies (Kuru, Jos) Tunji Olaopa wrote in The Guardian (April 9, 2020), that in a pandemic situation like the current one, it's hard not to think about the end of the world, and very 
few succeed. As well as, in fact, the conspiracy theory or the development of biological weapons of one country against another, in this case China (the version of the artificial origin of the virus from Wuhan's laboratory is widely discussed at various levels). Eschatological views, such as "God's providence" the aim of which is to punish humanity or call for repentance, which is typical of fundamental beliefs, can easily fit into a person's religious experience under the influence of extraordinary events. More "intellectually oriented" eschatological systems use the situation of uncertainty with the coronavirus to call for a better understanding of the modern world [13].

When discussing the problem of eschatology in connection with the Covid-19 pandemic, the role of the church in spreading not only the idea of a pandemic but also the coronavirus itself cannot be overlooked. Using the situation of uncertainty caused by the pandemic to their advantage, some religious communities and their leaders, as well as entire denominations, have unfortunately led to a significant increase in coronavirus casualties. Here are just a few illustrative examples from around the world. Thus, in South Korea, the center of the Covid-19 outbreak in March 2020 is the community of the Shincheonji Church of Jesus (Daegu). Pastors of some local churches in Trinidad, contrary to the recommendations of state authorities and local administration, insisted on the personal presence of believers in worship, bullying those members of the community who did not obey them, accusing them of "lack of faith". In the United States, Rev. Tony Spell, pastor of Life Tabernacle Church, a Oneness
Pentecostal congregation in Baton Rouge, explained the disobedience to the quarantine authorities by violating the "religious rights" he urged his community to abide by. Moreover, the personal presence of believers during community gatherings is interpreted by him as a "test of faithfulness" [14: 115]. An illustrative example in this context is the position of the Ukrainian Orthodox Church (MP), which not only ignored the government's recommendations to conduct religious activities online, but also called on people to violate or ignore them. In the absence of a ban on religious activity in Ukrainian law, as well as the fact that the pandemic period fell on the Easter cycle of Orthodox holidays, among the centers of the Kovid-19 outbreak in Ukraine were Orthodox centers of religious life belonging to the UOC (MP).

R. Bultman, one of the founders of dialectical theology, explores the term eschatology in its procedural aspect, emphasizing not so much the "last things" as those that mark the end of the world, but how, in what way "the world we know will come to an end". In his interpretation, the end of the world is identical with the process its disappearance and eschatology is interpreted as a doctrine of this process [15: 31]. And this is the comprehension of eschatology consistent with the eschatological views of modern man, immersed in an atmosphere of uncertainty in a rapidly changing world, in which there are no guarantees for the future. Accordingly, uncertainty causes fear and social anxiety, which is largely the basis for the idea of "the end of the world" get relevant.

Christian eschatology undergoes a process of "demythologization" (Bultmann), like all Christian theology, thus freeing itself from the "ballast of 
the past" and bringing Christian doctrine closer to modern realities, making it more understandable to people [16: 6]. In fact, the idea of eschatology is being transformed under the influence of global processes of today, especially the unexpected ones, which affect the fate of the entire global society and indicate uncertainty as a state in which the world is. Such uncertainty is an inexhaustible well of the formation and re-formation of eschatological ideas of both the past and their latest interpretation.

In our opinion, today as never before, the words by H. Briem, MD, PhD Special Advisor Centre for Health Security and Communicable Disease Control Directorate of Health: "The only certainty is the uncertainty" are true to life [17].

Uncertainty, as a lack of awareness in the current situation of everyday life of a person and society, also actualized another of the eschatological scenarios: conspiracy theory. This time the target was $5 \mathrm{G}$ technology, which may be responsible for the spread of coronavirus, according to one of the possible causes of the pandemic. In another variant, the competition for dominance (trade and technological struggle) in the provision of $5 \mathrm{G}$ communication between the United States and China has led to the emergence of coronavirus. Accordingly, it was developed in secret laboratories of China (according to other versions the United States) and distributed in the territory of a competitor (the United States or China). However, even before that, there was an accidental "leak" of the virus from a laboratory in China itself. In the superconspiratorial version, conspiracy theory combines these two versions of the threat to humanity into one, even with elements 34 of Christian eschatology: the antichrist will soon manifest himself in social life, and the number 666 will reveal its significance as well [13].

It is worth emphasizing that the actualization the deepest fears of man the fear of death in particular, while this pandemic, raises the question of understanding and rethinking one's own value sphere. Awareness of one's own mortality as one of the basic existentials of a person is a factor in the formation of human personality, and today more than ever man has the opportunity to experience in practice Heidegger's "death as a way of being", which helps being to acquire integrity [18: 8]. On the other hand, the value of eschatological prophecies and predictions is limited when it comes to the real threat to life [13]. So why not consider the eschatological concept as a stimulus to improve the inner intentions of a person as a humanist, which are extremely important in such a complex situation as the Kovid-19 pandemic.

Conclusions and research perspectives. To live in a world full of rapid change and a significant number of uncertain situations means to be the bearer of eschatological views on a conscious or unconscious level. Bringing deep human fears, such as fear of death, into the realm of active understanding, occurs under the influence of global shocks, such as pandemics. When the main characteristic of the future (as well as the present) is uncertainty, the absence of any guarantees, it is difficult to avoid eschatological thoughts. The panic surrounding the Covid-19 pandemic is largely due to catastrophic multiscenarios, in which the threat to humanity comes from viruses of 
natural or anthropogenic origin, widely spread in the media.

The uncertainty of the modern world has heightened people's awareness of the need for strong social ties as safeguards against fear of death, social destruction or psychological discomfort.

In the current situation around the pandemic and the accompanying social anxiety, fears and threats, the awareness of the value of human life remains unchanged. Reflecting on the connection between eschatology and Covid-19, the expectation that terrible prophecies will come true, should not push the awareness of the danger of the pandemic itself out of the human mind.

Eschatology in this sense, paradoxically, is a form of overcoming uncertainty and social anxiety as its consequence, and therefore performs a positive social function: contributes to the actualization of ways to overcome the tragedy of the situation of uncertainty in everyday life and fear of its consequences. And the perception of the eschatological motive of reality in this aspect leads to the importance of a person's values re-interpretation, which should be made with a focus on ensuring the integrity of human existence and society.

\section{LITERATURE}

1. Арсенов О. Конец света глазами науки / Олег Арсенов. Москва: Эксмо, 2011. 224 c.

2. Аверинцев С. Софія Словник. 3-е вид. / Сергій Аверинцев. Київ: Дух і мітера, 2007. 650 с.

3. Фоменко М. Світоглядні витоки сучасної есхатологічної свідомості: автореф. дис. на здобуття наук. ст. кандидата фікософських наук: спец. 09.00.03 "Соц. філософія та філос. історії" / Марина Фоменко. Донецьк, 2007. 18 с.

4. Гранин Р. Эсхатологические исследования в России XXI века: Аналит. обзор / РАН. ИНИОН. Центр гуманит. науч.-информ. исслед. Отд. фимософии; Отв. ред. Хлебников Г. В. М., 2017. 101 с.

5. Михина М. Неопределенность: основные характеристики и определение. Инновационная наука. № 5-2. 2018. C. $140-143$.

6. Brito U. The Eschatology of Covid19, An Introduction [Електронний ресурс]. Режим доступу: http:/ / kuyperian.com/the-eschatology-ofcovid-19-an-introduction/

(дата звернення: 6.05.2020).

7. Bhandari M. The phobia corona (COVID 19) - What we can do. ASEJ Scientific Journal of Bielsko-Biala School of Finance and Law Volume 24, No 1 (2020), PP. 1-3.

8. Juhl J. Putting the Terror in Terror Management Theory: Evidence That the Awareness of Death Does Cause Anxiety and Undermine Psychological Well-Being / Jacob Juhl. Current Directions in Psychological Science 25(2). December 2015. [Електронний ресурс]. Режим доступу : https://www.researchgate.net/publication/ 299427883_Putting_the_Terror_in_Terror_ Management_Theory_Evidence_That_the_A wareness_of_Death_Does_Cause_Anxiety_a nd_Undermine_Psychological_Well-Being (дата звернення: 04.05.2020).

9. Пожаров А. Трансформации христианского эсхатологического мифа в современном медиакультурном пространстве : автореферат дис. на соискание научн. ст. кандидата культурологи : спец. 24.00.01 "Теория и история культуры" / А^ексей Игоревич Пожаров. М.: НОУ ВПО «Гуманитарный институт телевидения и радиовещания имени М. А. Аитовчина", 2015. - 26 с. [Електронний ресурс] Режим доступу: sias.ru/upload/ds-

pozharov/Avtoref_Pozharov.doc (дата звернення: 03.05.2020).

10. Пророчества о коронавирусе. [Електронний ресурс]. Режим доступу: https://sonnik.expert/stati/predskazaniyao-koronaviruse-158945/\#ftoc-heading-12 (дата звернення: 03.05.2020). 
11. Титова Ю. "Создатель" COVID-19: как Бим Гейтс стал объектом атаки сторонников теории заговора. [Электронный ресурс]. Режим доступа: https://www.forbes.ru/milliardery/399237 -sozdatel-covid-19-kak-bill-geyts-stalobektom-ataki-storonnikov-teorii-zagovora (дата обращения: 02.05.2020).

12. Kettley S. Coronavirus: Forget Nostradamus, people think Madonna predicted the COVID-19 pandemic. [Електронний ресурс]. Режим доступу: https://www.express.co.uk/news/weird/ 1 258476/Coronavirus-Nostradamusprediction-Madonna-COVID-19-pandemiclatest-news (дата звернення: 03.05.2020).

13. Olaopa T. Coronavirus, conspiracy theories and 'end time' eschatology/Tunji Olaopa. [Електронний ресурс]. Режим доступу:

https:/ / guardian.ng/opinion/coronavirusconspiracy-theories-and-end-time-

eschatology/ (дата звернення: 05.05.2020).

14. Wildman W., Bulbulia J., Sosis R., Schjoedt U. Religion and the COVID-19 pandemic / Wesley J. Wildman, Joseph Bulbulia, Richard Sosis, Uffe Schjoedt. Religion, Brain \& Behavior. Volume 10, 2020. P. 115.

15. Бультман Р. История и эсхатология. Присутствие вечности: Монография / Рудольф Бультман. Пер. с англ. А. М. Руткевич. Москва: "Канон +" РООИ "Реабилитация", 2012. 208 с.

16. Докаш В. Нова ортодоксія як рух за модернізацією есхато-сотеріологічних доктрин християнського вчення / Віталій Докаш. Релігія та Соціум. 2013. №2(10). C. 5-14.

17. Briem H. COVID-19. The only certainty is the uncertainty. [Електронний ресурс] Режим доступу: https://www.ncbi.nlm.nih.gov/pubmed/32 124733 (дата звернення: 02.05.2020).

18. Вітюк I. Страх перед смертю як передумова есхатологічних візій. // Українська помоністика. 2015. Випуск 12. C. 3-10.

\section{REFERENCES (TRANSLATED AND TRANSLITERATED)}

1. Arsenov, O. (2011). Konets sueta glazami nauki [End of the world through the eyes of science]. Moscow: Eksmo (in Russian).

2. Averyntsev, S. (2007). Sofiya Lohos. Slovnyk. 3-e vyd. [Averintsev S. Sofia - Logos. Dictionary]. Sergey Averintsev. Kiev: Spirit and Letter, (in Ukrainian).

3. Fomenko, M. (2007). Svitohlyadni vytoky suchasnoyi eskhatolohichnoyi svidomosti [Worldview origins of modern eschatological consciousness: author's ref. dis. for PhD: special. 09.00.03 "Social philosophy and philosophical history" / Marina Fomenko]. Donetsk (in Ukrainian).

4. Granin, R. (2017). Eskhatologicheskiye issledovaniya $v$ Rossii XXI veka [Eschatological research in Russia in the XXI century: Analyt. Review] / RAS. INION. The center is humanistic. scientific-inform. research. Dept. philosophy; Ed. Khlebnikov GVM (in Russian).

5. Mikhina M. Neopredelennost': osnovnyye kharakteristiki i opredeleniye [Uncertainty: main characteristics and definition]. Innovative science. No. 5-2. 2018. 140-143 (in Russian).

6. Brito, U. The Eschatology of Covid19, An Introduction [Електронний ресурс]. Режим доступу : http://kuyperian.com/the-eschatology-ofcovid-19-an-introduction/ (last accessed: 6.05.2020) (in English).

7. Bhandari, M. The phobia corona (COVID 19) - What we can do. ASEJ Scientific Journal of Bielsko-Biala School of Finance and Law Volume 24, No 1 (2020), 1-3 (in English).

8. Juhl, J. Putting the Terror in Terror Management Theory: Evidence That the Awareness of Death Does Cause Anxiety and Undermine Psychological Well-Being / Jacob Juhl. Current Directions in Psychological Science 25 (2). December 2015. [Electronic resource]: access mode: https://www.researchgate.net/publication/ 299427883_Putting_the_Terror_in_Terror_ Management_Theory_Evidence_That_the_A 
wareness_of_Death_Does_Cause_Anxiety_a nd_Undermine_Psychological_Well-Being (last accessed: 4.05.2020) (in English).

9. Pozharov, A. (2015). Transformatsii khristianskogo eskhatologicheskogo mifa $v$ souremennom mediakul'turnom prostranstve [Transformations of Christian eschatological myth in modern media and cultural space]: dissertation abstract. for $\mathrm{PhD}$ : special. 24.00.01 "Theory and history of culture" / Alexey Igorevich Pozharov. Mjscow: LEU VPO "Humanitarian Institute of Television and Radio Broadcasting named after MA Litovchin". [Electronic resource] access mode: sias.ru/upload/dspozharov/Avtoref_Pozharov.doc] (last accessed: 03.05.2020) (in Russian).

10. Prorochestva o koronavyruse [Prophecies of the coronavirus] [Electronic resource] access mode: https://sonnik.expert/stati/predskazaniyao-koronaviruse-158945/\#ftoc-heading-12 (last accessed: 03.05.2020) (in Russian).

11. Titova, Yu. "Sozdatel"' COVID-19: kak Bill Geyts stal ob"yektom ataki storonnikov teorii zagovora ["Creator" of COVID-19: How Bill Gates Become the Object of Attack by Conspiracy Theory] [Electronic resource]. Access mode: https://www.forbes.ru/milliardery/399237 -sozdatel-covid-19-kak-bill-geyts-stalobektom-ataki-storonnikov-teorii-zagovora (last accessed: 02.05.2020) (in Russian).

12. Kettley, S. Coronavirus: Forget Nostradamus, people think Madonna predicted the COVID-19 pandemic. [Electronic resource]: access mode: https://www.express.co.uk/news/weird/ 1 258476/Coronavirus-Nostradamusprediction-Madonna-COVID-19-pandemiclatest-news (last accessed: 03.05.2020) (in English).

13. Olaopa, T. Coronavirus, conspiracy theories and "end time" eschatology/Tunji
Olaopa. [Electronic resource]: access mode: https://guardian.ng/opinion/coronavirusconspiracy-theories-and-end-timeeschatology/ (last accessed: 05.05.2020) (in English).

14. Wildman, W., Bulbulia, J., Sosis, R., Schjoedt U. Religion and the COVID-19 pandemic / Wesley J. Wildman, Joseph Bulbulia, Richard Sosis, Uffe Schjoedt. Religion, Brain \& Behavior. Volume 10, 2020, 115 (in English).

15. Bul'tman, R. (2012). Ystoryya $y$ eskhatolohyya. Prysutnstvye vechnosty [History and eschatology. Presence of eternity]: Monohrafyya / Rudol'f Bul'tman. Per. s anhl. A. M. Rutkevych. Moscow: "Kanon +" ROOY "Reabylytatsyya" (in Russian).

16. Dokash, V. Nova ortodoksiya yak rukh za modernizatsiyeyu eskhatosoteriolohichnykh doktryn khrystyyans' koho vchennya [New orthodoxy as a movement for the modernization of eschato-soteriological doctrines of Christian doctrine]. Religion and Socium. 2013, №2 (10), 5-14. (in Ukrainian).

17. Briem, H. COVID-19. The only certainty is the uncertainty. [Electronic resource] access mode: https://www.ncbi.nlm.nih.gov/pubmed/32 124733 (last accessed: 02.05.2020) (in English).

18. Vityuk, I. Strakh pered smertyu yak peredumova eskhatolohichnykh viziy [Fear of death as a prerequisite for eschatological visions]. Ukrainian Polish studies. 2015. Issue 12, 3-10 (in Ukrainian).

Receive: May 07, 2020 Accepted: June 17, 2020 